\title{
ポリマーミセルを用いた新たなドラッグキャリアシステム
}

\author{
横山昌幸・岡野光夫・桜井靖久*1), 片岡一則*2)
}

\section{A novel drug carrier system with polymeric micelles}

Concept and methodology of micelle-forming polymeric drug is reviewed. Drug targeting using drug carriers had been studied with three types of carriers; liposomes, microspheres, and polymers. Now however, a successful example of drug targeting using any drug carrier has not been obtained because of low performance of drug carriers. A novel type of drug carrier system, micelle-forming polymeric drug is presented here. Polymeric micelles were constructed by amphiphilic structure of drug-polymer conjugate using a block copolymer. Expected superior features of the polymeric micelles as a drug carrier are long half-life in bloodstream, high water solubility, no long term-accumulation, high stability etc. Furthermore, functions which are needed for the ideal drug carrier can be shared by different polymer segments which become outer shell and inner core of the micelle.

This separated functionality is favorable to get highly functionalized drug carrier system. Several unique characters and superior performance of the micelleforming polymeric drug to the conventional drug carrier systems are described by the authors' work which is a conjugate of anticancer drug, adriamycin and poly (ethylene glycol) -poly (aspartic acid) block copolymer.

Masayuki Yokoyama $\cdot$ Teruo Okano. Yasuhisa Sakurai ${ }^{* 11}$, Kazunori Kataoka*2)

key words : polymeric micelle, polymeric drug, drug targetmg, drug carrier

ドラッグターゲティングのためのドラッグキャ リアシステムのなかで, 従来にはない新しい形態 であるポリマーミセル(高分子ミセル)を用いたシ ステムについて，その方法論を中心に実例を交え てまとめてみる。

ドラッグターゲティングとドラッグキャリア

ドラッグターグティングとは, 病変臓器, 組織, 細胞にのみ選択的に薬物を運び, そこでの, 薬効 を選択的に高めて, 他の正常部位への副作用をな くす方法論である。これは, 図 1 に示すように, 標的部位への運搬能力を持つキャリアと薬理作用

-1) Institute of Biomedical Engineering, Tokyo Women's Medical College 果京女子医科大学医用工学研究施設

*2) Department of Materials Science and Technology, Faculty of Industrial Science and Technology, Science Uniuersrty of Tokyo 東京理科大学基磘工学部材料工 学科

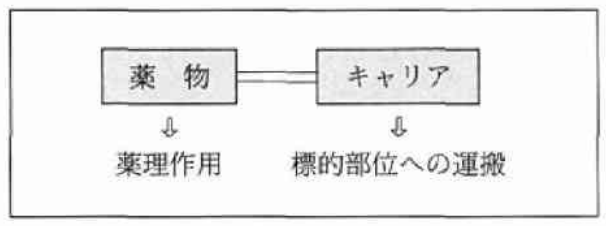

図 1 ドラッグターゲティングの方法

を有する薬物とを組み合わせて，選択的な薬効を 得るというものである.この考えかたそのものは 非常に単純で明解であり，また，これに関する研 究例の多さ (特に最近 15 年間) と歴史の深さ (源は P. Ehrlich にまで遡れる)にもかかわらず，1990 年現在において実用化に至ったものはない. その 理由は, 現在までに得られているキャリアの性能 が低いためである、ドラッグキャリアとして求め られる性能・性質は, 図 2 に示すように数多く, キャリアの設計は複雑なものに思われる. 


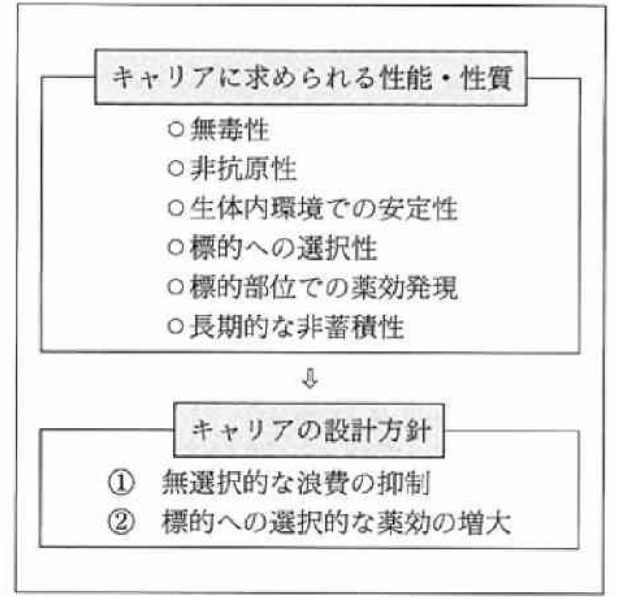

図 2 ドラッグキャリアの渵たすべき要件 と設計方針
しかし, ながら, 視点を変えてみると, ドラッ グキャリアの設計方針は図 2 の下側に示すよう に, 無選択的な浪費の抑制と標的への選択的な薬 効の増大とに集約される。現在までのドラッグ キャリアの研究の多くは(2)の方針にのみ重点が置 かれ，(1)についての研究は少ない. 無選択的な浪 費が十分に少なくなったときにはじめて，標的へ の選択性向上の検討が有効なものになると考えら れる.

\section{ドラッグキャリアの種類}

ドラッグキャリアとして従来から研究されてき たものを大別すると, リポソーム，ミクロスフィ ア，ポリマー(天然扔よび合成)となり，それぞれ 長所とともに少なからず欠点を抱えている、リポ ソームでは in vivo 環境下での不安定さ ${ }^{1 \sim 4)}$, ミク ロスフィアでは細網内皮系による取り込み ${ }^{5)}$ ，ポ リマーでは疎水性薬物導入による水溶性の低 下6,7)などである。

ここにあげた欠点はいずれも前節で述べた無選 択的な浪費につながるものであり，この克服のた めには各キャリアの性質の改善とともに, 新しい タイプのキャリアによる不連続的な飛躍が望まれ るところである。

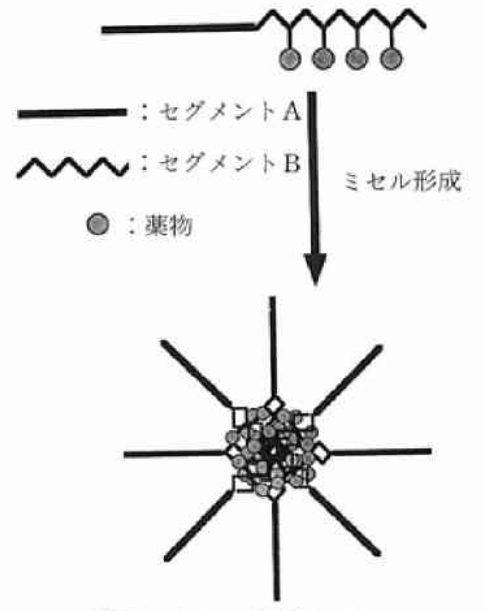

图 3 ミ七ル形成型ポリ メリックドラッグ の概念
ドラッグキャリアとしての高分子ミセル : ミセ ル形成型ポリメリックドラッグ

高分子ミセル型ドラッグキャリアシステムは, 図 3 に示すように，二つのポリマーセグメントよ りなる $\mathrm{AB}$ 型のブロックコポリマーのうち, 片方 のセグメントにのみ薬物を導入し，その薬物導入 セグメントを疎水性に，もう一つのセグメントを 親水性にした薬物ープロックコポリマー複合体に よって構成される。この複合体は両セグメントの 両親媒性により，水系の溶媒中で㻋水性の薬物導 入セグメントを内核に, 親水性セグメントを外殼 にした高分子ミセルを形成する，薬物導入セグメ ントの疎水性は, 導入する薬物または疎水性のポ リマーセグメントによって与えられる，また，高 分子ミセルを形成させるための必要条件は高分子 の不均質な構造であることなので, 図 3 の構造の ほかに,グラフトコポリマーも有力な候補となる. ただし，エントロピー的なミセル形成のしやすさ と,ポリマーの構造と形成するミセルの構造(大き さなど)の対応性を考慮すると, ブロックコポリ マーの方が好ましいと思われる。

さて，このミセル形成型ポリメリックドラッグ の特長はなにかについて考えてみたい.この命題 を別の言葉でいえば, 1 本 1 本遊離した形態では， たんなるポリマードラッグであるものがミセルを 形成する意義がなんであるかということになる. この点を表 1 にまとめる. 
表 1 ミセル形成型ボリメリックドラッグの特長

○ながい血中半減期のための適切な粒子径 ○長期での非蓄筫性

○高い水溶性

○高い楽物安定性

○構成ポリマーセグメントへの機能分化 その他

まず第一にあげられるのが，ミセルの粒子径で ある，高分子ミセルは，その構成ポリマーが1本 1 本遊離して存在する場合にくらベて，はるかに 大きな粒子として血液中などに存在する．この粒 子徍を適切に調節することにより，腎㖑における 排出を抑えてながい血中半減期を達成する. 加え て, 構成ポリマーの分子量の設計において, ミセ ルの状態と平衡関係で存在する遊離ポリマーの形 が体外へ排出されるようにしておけば，長期的な 蓄積による毒性も防ぐことができる.

つぎに良好な水溶性があげられる。一般に，疎 水性の薬物を高分子鎖に導入する場合は, 薬物と 高分子の複合体の水溶性が失なわれやすい，それ は，高分子鎖に沿って疎水基が局在化することに より，高分子鎖内および高分子鎖間での疎水性相 互作用が起こりやすく，その結果，凝集・沈殿生 成に結びつくためである。高分子ミセルの場合に は, 疎水性の内核同志が凝集して不溶の沈殿にな ることを親水性の外殼が抑制する。つまり，通常 のポリマーの場合には水溶性を失なわせる“悪玉” である疎水性が，高分子ミセル型ドラッグの場合 には，良好な水溶性を有する安定なミセル構造を 構築する推進力になるという“善玉”として利用 されることになる.

さらに, ミセルの内核に保持された楽物は，体 内の酵素などによる不活性化から免れるために， 薬物としての高い安定性が得られる。

また，構成ポリマーセグメントへの機能分化と は図 4 に示すようにドラッグキャリアとして果 たす役割のうち，ミセルの内核を形成するセグメ ントは薬物の結合と放出の役割を果たし，外殼を 構成するセグメントには蛋白質, 細胞やその他の 生体成分との相互作用を担わせる。これらの相互 作用は，このミセルの生体内での動態を決定し， 内核はその動態に基づいて標的に到達したあとの

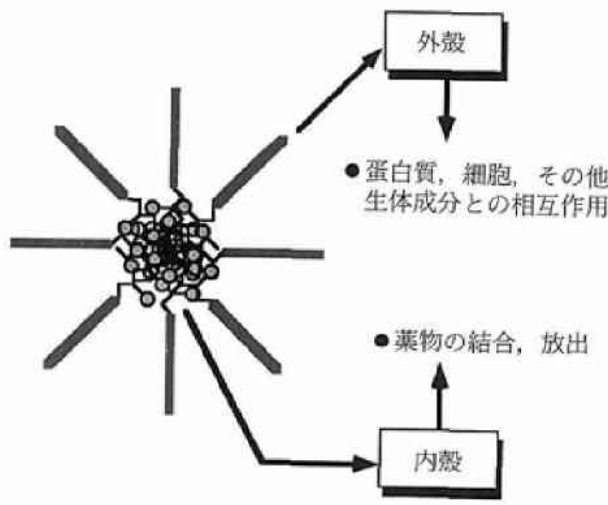

図 4 高分子ミセルによる機能分化

薬効発現を行うことになる，このような機能の各 セグメントへの分担は, より高機能のドラッグ キャリアの設計・作製を可能にする.

以上述べてきたような高分子セミルのドラッグ キャリアとしての特長のいくつかはすでに実証さ れているので，つぎに触れたい．

\section{ドラッグキャリアとしての高分子ミセルの研究} 例

高分子ミセルの形態を薬物の徐放に利用しよう とするアイデアは, 1984 年に Ringsdorf $ら^{8,9} に$ よって発表されていたが，ミセル形成の証拠が希 薄で, ミセルの形態を生体内でのドラッグデリパ リーに応用するまでは到らなかった，

また, Kopeček ${ }^{7,10)}$ らは, 疎水性の薬物を親水性 のホモポリマーの側鎖に結合させることでも，こ の薬物一ポリマーの複合体が数分子会合してミセ ル構造を形成することを報告している。しかしな がら,ミセル形成型のポリメリックドラッグとい う明確な概念の下の仕事は現在まで筆者らのグ ループ11 15)のものだけである. そのなかの結果の いくつかをまとめてみたい.

\section{（1）ミセル形成}

図 5 に示す構造を有する薬物一プロックコポリ マー複合体 PEG-P(Asp (ADR)) は, 親水性のポリ エチレングリコールセグメントを外款に，抗癌剤 アドリアマイシン結合したポリアスパラギン酸セ グメントを疎水性の内核とした高分子ミセルを形 成する，その様子を示したのが図 6 で, pH7.4の リン酸等張液中で数平均約 $50 \mathrm{~nm}$ の粒子として 


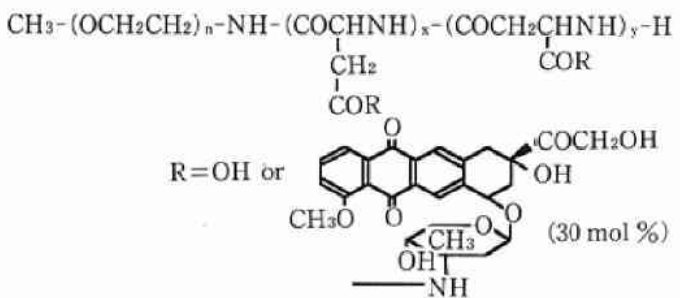

図 5 ミセル形成型ポリメリックドラッグ PEG-P(Asp(ADR))の構造式

分子量 PEG：4300, P(Asp) : 1900

$\beta$-アミド化率: $\mathrm{X} /(\mathrm{X}+\mathrm{Y})=80 \mathrm{~mol} \%$

存在していることがわかる，界面活性剤ドデシル 硫酸ナトリウム(SDS)の添加によりミセルの ピークはすべて低分子量側にシフトすることか ら，このミセルが設計どおり非共有結合的な相互 作用によって形成されていることがわかる.

また，なんの精製操作なしで，単一で狭い分布 のミセル径で得られたのは，この高分子ミセルの すぐれた特長といえる，というのは，同じく分子 の集合体であるリポソームの場合には，さまざま な形態の混合物で粒径分布の広いものとして得ら れるのがつねだからである。

\section{（2） 水溶性 ${ }^{14)}$}

図 5 に示した PEG-P(Asp(ADR))は, 疎水性の 強いアト゚リアマイシンを多く導入しているにもか かわらず，きわめて良好な水溶性を有している。 アドリアマイシン自体がゲル状になる高濃度, 高 イオン環境下においても PEG-P(Asp(ADR))の 水溶性は失なわれず，まだ凍結乾燥後も再び水溶 液に戻すことが可能である.

一般に，ポリメリックドラッグでは，キャリア への結合の際にドラッグが極性基を失なううえ に，キャリアに沿って疎水基が局在するために結 合前の薬物よりも水に溶けにくくなる.この高分 子ミセルの場合は逆にもとの薬物よりもすぐれた 水溶性を示すようになる。これは, ミセル構造を とることによって, 疎水性部分を一定領域に隔離 しとどめることが安定してできるためと考えら れ，ミセル形成型ポリメリックドラッグの利点の 一つに数えられる。

（3）セグメントへの機能分化 ${ }^{14,16)}$

ミセル形成型ポリメリックドラッグ PEG-P $(\mathrm{Asp}(\mathrm{ADR}))$ に使用されている抗癌剤アドリアマ
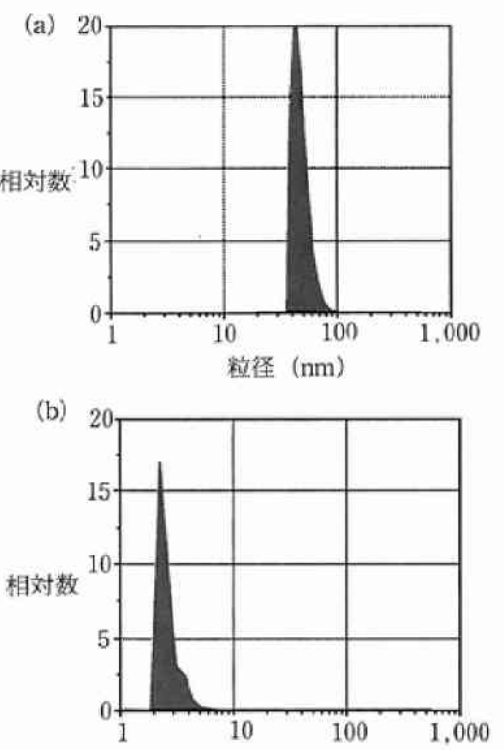

图 6 PEG-P(Asp(ADR)) の粒径分布 $\mathrm{pH} 7.4$ リン酸等張液中, $[\mathrm{ADR}]=0.1 \mathrm{mg} / \mathrm{m} l$ a : SDS 無添加 b : $1 \%$ SDS添加

イシンは疎水性が強く，血中投与した際の分布体 積が大きい、つまり，血中では体内の組織にすば やく分配・吸収され，血中濃度は投与量に対して 非常に少ない(静脈投与 5 分後で投与量の 2 〜 $3 \%$ 程度しか血中に見出せない).さらに血中で は, その強い疎水性のためにその多く(50～90\%の 程度)がアルブミンに結合した形で存在している. このアドリアマイシンの性質をブロックコポリ マーに結合させて,複合体 PEG-P(Asp (ADR)) に することで劇的に変化させることができる。

すなわち, PEG-P(Asp(ADR)) は, アルブミン とはまったく相互作用せずにミセルとして存在す ることが観察されている。 また，静脈注射におい て，血中での高い濃度がみられた。アドリアマイ シン換算 $20 \mathrm{mg} / \mathrm{kg}$ 投与量で投与 5 分後に，血中 ではその投与量の約 $60 \%$ に相当する量が確認さ れた。これは，アドリアマイシンの場合の量の 30 倍ほどに達する。ささらに，血中半減期も 70 分とア ドリアマイシンの数倍になった.

以上のように, 高分子ミセル PEG-P(Asp $(\mathrm{ADR}))$ は，アルブミン結合と血中での挙動にお 
いてアドリアマイシンとまったく異なる性㙺を有 することが見出された.この大きな変化は，ミ七 ルの外殼が, アドリアマイシンの結合した内核を 覆うことで, 血液成分とアドリアマイシンの相互 作用を抑制したためにもたらされたと考えられ る.

アルブミン結合能や血中漕度などは体内での動 態・分布を決める重要な因子であり，これを制御 することは in vivo drug delivery を行ううえで きわめて大切な事項である. そして,この制御を 行うに際して, 外殼と内核という二つの独立した 構造を有する高分子ミセルは有力な手段を与える のである.

\section{文 献}

1) Gregoriadis, G., Kirby, C., Large, P. : Targeting of Liposomes: Study of Influencing Factors. Targeting of Drugs., Plenum Press, 1982, p 155-184.

2) Gregoriadis, G., Senior, J. : Fate of Liposomes in vivo: Control Leading to Targeting. Receptor Mediated Targeting of Drugs., Plenum Press, 1984, p 243-266.

3) Gabizon, A., Papahadjopoulos, D. : Liposome formulations with prolonged circulation time in blood and enhanced uptake by tumors. Proc. Natl. Acad. Sci. USA $85: 6949-6953,1988$.

4) Allen, T.M., Chonn, A. : Large Unilamellar Liposomes with Low Uptake into the Reticuloendo thelial System. FEBS Letters 223: 42-46, 1987.

5) Davis, S.S., Illum, L. : Colloidal Delivery Systems: Opportunities and Challenges. Site-Specific Drug Delivery. John Wiley \& Sons, 1986, p 93-110.

6) Endo, N., Umemoto, N., Kato, Y., Takeda, Y., Hara T. : A Novel Covalent Modification of Antibodies at Their Amino Groups with Retention of AntigenBinding Activity. J. Immunol. Methods $104: 253-$ 258, 1987.

7) Duncan, R., Kopečková-Rejmanová, P., Strohalm, J., Hume, I., Cable, H.C., Pohl, J., Lloyd, J. B., Kopecek, J. : Anticancer Agents Coupled to N-(2hydroxypropyl)methacrylanide Copolymers. I. Evaluation of Daunomycin and Puromycin Conju- gates in vitro $\mathrm{Br}$. J. Cancer $55: 165-174,1987$.

8) Bader, H., Ringsdorf, H., Schmidt, B. : Watersoluble Polymers in Medicine., Angew. Makromol. Chem. 123/124: 457-485, 1984.

9) Pratten, M. K., Lloyd, J. B., Hörpel, G., Ringsdorf, $\mathrm{H}$. : Micelle-forming block copolymers: $\mathrm{Pi}$ nocytosis by macrophages and interaction with model membranes., Makromol. Chem. 186: 725733,1985 .

10) Ulbrich, K., Konak, C., Tuzar, Z. Kopeček, J. : Solution Properties of drug carriers based on poly [N-(2-hydroxypropyl) methacrylamide] containing biodegradable bonds, Makromol. Chem. 188 : 12611272, 1987.

11) Yokoyama, M., Inoue, S., Kataoka, K., Yui, N., Sakurai, Y. : Preparation of Adriamycin-conjugated poly (ethylene glycol) -poly (aspartic acid) block copolymer, Makromol. chem. Rapid, Commun. 8: 431-435, 1987.

12) Yokoyama, M., Inoue, S., Kataoka, k., Yui, N., Okano, T., Sakurai, Y.: Molecular design for missile drug : Synthesis of Adriamycin conjugated with IgG using poly (ethylene glycol)-poly (aspartic acid)block copolymer as intermediate carrier. Makromol. Chem. 190 : 2041-2054, 1989.

13) Yokoyama, M., Miyauchi, M., Yamada, N., Okano, T., Sakurai, Y., Kataoka, K., Inoue, S. : Polymer Micelles as Novel Drug Carrier: Adriamycin-conjugated Poly (ethylene glycol)-poly (aspartic acid) Block Copolymer. J. Contr. Rel. 11 : 269-278, 1990.

14) Yokoyama, M., Miyauchi, M., Yamada, N., Okano, T., Sakurai, Y., Kataoka, K., Inoue, S. : Characterization and Anticancer Activity of the Micelleforming Potymeric Anticancer Drug Adriamycinconjugated Polycethylene glycoll-Poly(aspartic acid) Block Copolymer. Cancer Res. $50: 1693-1700$, 1990.

15）横山昌幸, 山田則子, 岡野光夫, 桜井靖久, 片岡一則, 井上祥平：新規ブロックコボリマーを用いた合成した ミセル形成能を有するポリマードラッグ、人工臟器 $19: 1239-1242,1990$.

16）横山昌幸, 風野光夫, 桜井靖久, 片岡一則：ブロック コポリマーと抗ガン郕アドリアマイシンより成る高分 子ミセルドラッダの血中挙動. 第 6 回日本 DDS 学会 予稿集. DDS 5 : 169, 1990 . 